\title{
Significance of anecdotes for historical perspective: black bear predation on sea turtle eggs
}

\author{
Karen A. Bjorndal ${ }^{*}$
}

Archie Carr Center for Sea Turtle Research and Department of Biology, University of Florida, Gainesville, FL 32611, USA

\begin{abstract}
In his April 2010 TED talk on the shifting baseline syndrome, Daniel Pauly warned us that 'we transform the world, but we don't remember it.' This lapse is the greatest obstacle to understanding and restoring the structure and function of ecosystems transformed by anthropogenic effects over past centuries or even over the past few decades. Historical anecdotes can be a powerful tool to address gaps in our knowledge of the past. I present a case study to demonstrate the use of anecdotes to reveal the extensive predation by black bears Ursus americanus on sea turtle eggs in Florida, USA. Until the late 1800s, bears were major predators on eggs deposited by the large sea turtle aggregations nesting on the east coast of Florida. However, this past source of mortality, and the resulting substantial transport of nutrients from marine to terrestrial habitats via the bears, are largely unknown today. By the early 1900s, the great influx of humans to the east coast of Florida quickly decimated the bear populations by hunting and habitat degradation. Without historical anecdotes, knowledge of the extensive predation by black bears on sea turtle eggs in Florida would have been lost.
\end{abstract}

KEY WORDS: Shifting baseline syndrome $\cdot$ Marine turtle $\cdot$ Black bear $\cdot$ Predation $\cdot$ Florida coastal ecosystem $\cdot$ Nutrient transport $\cdot$ Loggerhead

\section{INTRODUCTION}

As Jackson (2001, p. 5411) stated, 'our concept of what is natural today is based on personal experience at the expense of historical perspective.' This brief statement summarizes why the shifting baseline syndrome (SBS; Pauly 1995, 2010) is a great threat to environmental conservation. The SBS results in inappropriate baselines against which to measure environmental change, thus increasing our tolerance for environmental loss (Soga \& Gaston 2018). How can we restore ecosystems without knowledge of what has been lost? Pauly (1995) emphasized the power of incorporating anecdotes from historical accounts into modern fisheries models as part of the solution.

Paleoecological, archeological, and historical data are the best sources of information on the structure

*Corresponding author: bjorndal@ufl.edu and functioning of past ecosystems for understanding and recreating those ecosystems (Jackson et al. 2001, Pitcher 2001, Bjorndal \& Bolten 2003, Pandolfi et al. 2003). Anecdotal accounts from past centuries can help counter the SBS and provide information on selective pressures that shaped ecosystems, particularly with improved knowledge of food webs, interspecific competition, and population regulation. Greater understanding of the scope of anthropogenic effects, particularly how early these major pressures started, can improve management of modern ecosystems.

In this paper, I review anecdotes to reconstruct the historical importance of black bear Ursus americanus predation on sea turtle eggs in Florida, USA, and discuss implications of this little-known interaction.

() The author 2020. Open Access under Creative Commons by Attribution Licence. Use, distribution and reproduction are unrestricted. Authors and original publication must be credited. 


\section{HISTORICAL ACCOUNTS}

The earliest account of predation by black bears on sea turtle eggs that I found was by Bernard Romans in his survey of the east and west coasts of Florida between 1769 and 1771 (Romans 1775, p. 283-284):

'During the season the loggerhead turtles land here [Jupiter Island] in vast multitudes, to lay their eggs, which the bears profit by; for, led by instinct, or otherwise, these animals come in droves, and dig the eggs out... So industrious are the bears at digging up the eggs, that the turtle seldom leaves her nest above a quarter of an hour before they are eaten, insomuch, that a traveller, if he choses any of this provision, is obliged to watch the turtles coming. I have seen the bears approach within five or six yards of our camp, at times when we had some of these eggs, but this stretch of latronical boldness, generally cost them their lives.'

After learning about bears as past predators from Romans, I discovered that very few of the sea turtle biologists with whom I spoke knew of this phenomenon. With the exception of Dodd (1988), published reviews of sea turtle predators do not include bears (Stancyk 1982, Witzell 1983, Hirth 1997, Heithaus 2013).

Further research revealed several anecdotal accounts of bears feeding on sea turtle eggs, reviewed below. All reports were from the east coast of Florida, and all are consistent with the description by Romans (1775). I did not make a complete review of Florida newspapers that undoubtedly would have yielded many more anecdotes. The most complete accounts are those by J. M. Murphy (1890) and a letter written by Wenzel J. Schubert to Archie Carr on 14 June 1961. In his letter, Schubert described his experiences as a sea turtle egg collector when he was a boy on Hutchinson Island, Florida, from about 1894 to 1905. This letter, brought to my attention by George Balazs, may be found in the Supplement at www.intres.com/articles/suppl/n043p353_supp.pdf.

Although the distributions of black bears and sea turtle nesting would have overlapped along many Florida beaches (FWC 2019), predation by black bears on sea turtle eggs was only reported in early accounts from Merritt Island (Barbour 1944) south to Cape Florida (Munroe 1893), a distance of about $300 \mathrm{~km}$ (Fig. 1). Other accounts of bears eating sea turtle eggs in this region in addition to those discussed in this paper include a description of an encounter on a beach east of Indian River (Webb 1887), a statement that pioneers in Palm Beach County had to be careful while collecting sea turtle eggs because eggs were the favorite food of bears (Pedersen \& DeVries 2012), and the recounting by the great naturalist Thomas

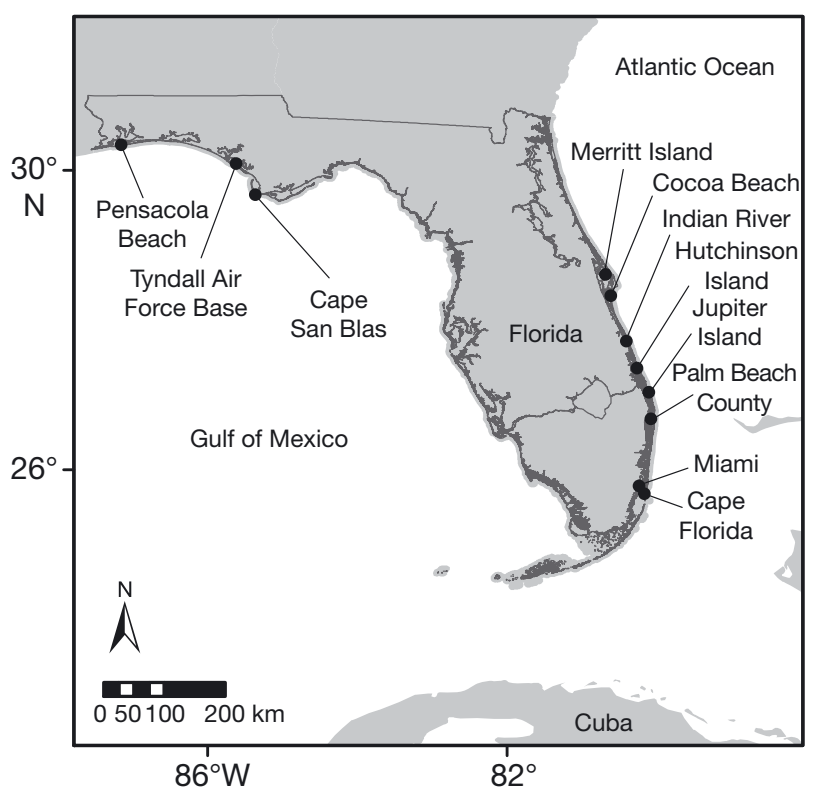

Fig. 1. Locations discussed in the text. Map was created in ArcMap version 10.6.0 (ESRI 2018) using data from FWCFWRI (2017), USGS (2018), and Williams (2004)

Barbour (1944, p. 143) of his childhood memory from about 1896 of seeing bear tracks on Merritt Island where the bears 'had been walking the ocean beach waiting for the loggerhead turtles to come ashore and lay their eggs.'

Black bears may have preyed on sea turtle eggs in other areas of the southeastern USA, but I found no records. The apparent geographic limit of this foraging activity suggests it may have been a learned, not intrinsic, behavior. That is, long before Romans visited Florida in 1770, one or a few bears learned this technique that then spread among other bears in the region through imitation. This behavioral phenotype was maintained in the population throughout following generations. Similar cases are the classic examples of tits (Parus spp.) in Britain learning to open milk bottles (Fisher \& Hinde 1949) and Japanese macaques Macaca fusca learning to wash sweet potatoes (Kawamura 1959). If these bears shared a learned behavior of feeding on sea turtle eggs, this behavior would have disappeared if the bear population died out.

Black bears were sufficiently abundant on the beaches during the sea turtle nesting season to consume almost all egg clutches shortly after they were deposited (Romans 1775, also indicated in the 1961 letter by Schubert). Bears would swim the Indian River to the coastal barrier islands to feed on sea turtle eggs (Dodge 1894). Murphy (1890, p. 80) reported 'A party of three of us killed five bears on the Indian 
River one night while they were searching for turtle eggs, and we might have slain more had not the sandflies bothered us so much as to affect our aim.' Bears were also very efficient: 'Both bears and raccoons possess the remarkable faculty of being able to go direct to a turtle's nest' (Murphy 1890, p. 80). Schubert reported that 'During my boyhood [ 1894-1905] only the bears robbed the nests, and up to the turn of the $\left[20^{\text {th }}\right]$ century they missed but few.' He echoed Romans in reporting that he had 'to cover the beach by moonlight and catch the turtles actually on the nest, or get there immediately after the eggs were laid, to beat the bears.' Individual bears could consume a large number of eggs. A single bear was reported to consume 200 eggs in one sitting (Dodge 1894) and 'devours as many [eggs] in twenty-four hours as a man would in a week' (Murphy 1890, p. 79).

Nesting by green turtles Chelonia mydas, always in smaller numbers than loggerheads Caretta caretta, is mentioned in several accounts (Murphy 1890, Dodge 1894, also in the letter by Schubert). All reports of bears consuming eggs either did not identify the species or stated they were loggerhead eggs. Loggerhead egg clutches would probably be more vulnerable to bears because they are substantially closer to the beach surface than those of green turtles (Dodd 1988, Hirth 1997). In addition, I found no reports of bears attacking nesting sea turtles; all reports only referred to bears eating sea turtle eggs. This diet selection is reasonable because eggs are easier to process - bears are efficient diggers - and have a much greater nutrient density than adult sea turtles.

In the $18^{\text {th }}$ and early $19^{\text {th }}$ centuries, humans killed relatively small numbers of bears along the Florida coast primarily for food or personal protection. The pressure from humans on both bears and sea turtle eggs increased in the late 1800 s, sometimes in combination. 'Quite a large party was over there [Cocoa Beach] last week, some at work, and some on pleasure bent. The hunters report killing two bear, and securing turtles, turtle eggs, clams, and many good things' (The Tropical Sun 1891). This pressure increased dramatically as Henry Flagler extended his Florida East Coast Railway along the Florida coast, opening the area to commerce and supporting a great expansion of the human population. The railway reached Palm Beach County in 1894 and Miami in 1896 (Standiford 2002). Coastal bear populations were soon decimated by hunting and habitat destruction.

The fate of bear populations on Hutchinson Island is relatively well documented and is probably represen- tative of the surrounding coastal region. Largely as a result of hunting, bears were rare by 1920, and reports of individual bears being killed were featured in newspaper accounts (summarized by Luckhardt \& Luckhardt 2012). Around 1918, a bear and her 2 cubs were killed, a bear was trapped in 1924, another was shot in 1925, and, finally, in 1931, the last bear on Hutchinson Island was shot by a beekeeper to prevent further depredations on his beehives.

\section{CURRENT CONDITIONS}

Since 1979, there has been no record of bears disturbing a sea turtle nest in Florida based on the Statewide Nesting Beach Survey Program Database of the Florida Fish and Wildlife Conservation Commission and the Florida Fish and Wildlife Research Institute (FWRI) as of 20 February 2020 (B. Mongiovi pers. comm.). After reaching a low point in the mid1900s, bear populations throughout Florida have increased as a result of conservation measures in areas where suitable habitat remains (FWC 2019). Coastline development has now greatly restricted access to most beach areas for black bear populations in Florida (Scott 2004). Bear populations are classified as 'rare' in the coastal areas along the southeastern coast of Florida, including the region covered in this paper, and will not recover unless habitat is recreated (FWC 2019).

The Florida Panhandle (northwestern Florida) is one of the more likely areas for bears and sea turtles to interact because of relatively large bear populations and extent of suitable bear habitat. Four sea turtle nest surveyors had not seen or heard of bears eating sea turtle eggs on Panama City Beach, Pensacola Beach, beaches on Tyndall Air Force Base, and beaches along Cape San Blas (Fig. 1) (M. M. Lamont pers. comm.). The last 3 areas have relatively large bear populations, but bears rarely come onto the beach in Pensacola and, although bear tracks are frequently seen on the beaches of Tyndall Air Force Base, no sea turtle nests have been disturbed there. Bear tracks are often seen on beaches of Cape San Blas, and bears are seen during night surveys, but no nest depredations have been reported. In May 1997, M. M. Lamont (pers. comm.) saw a dead immature loggerhead ( $50-60 \mathrm{~cm}$ carapace length) on Cape San Blas that had apparently stranded dead and was then dragged off the beach into the woods by a mother bear and 3 cubs and was presumably eaten.

These reports indicate that bears no longer prey on sea turtle nests. Bears are, however, patrolling beaches 
in some areas in search of food. At some point, particularly if bear populations continue to increase, bears may well learn that sea turtle nests are an excellent source of nutrition, teach their offspring and conspecifics, and re-establish the nest-raiding behavior phenotype.

\section{BIOLOGICAL AND MANAGEMENT IMPLICATIONS}

Recognition of black bears as major predators on sea turtle eggs in the past has important biological and management implications. If a new group of bears learns to prey on sea turtle eggs, this new foraging behavior could affect sea turtle populations. The small, genetically distinct loggerhead population that nests along the Panhandle of Florida (Shamblin et al. 2012) would be particularly vulnerable. Humans conducting nocturnal sea turtle patrols would have to prepare for increased, and possibly more aggressive, encounters with bears. Resource managers should consider concealing remains from nests partially destroyed by raccoons Procyon lotor or erosion to prevent bears from discovering that sea turtle nests provide nutritious prey.

We need to adjust our perception of what was natural in these coastal ecosystems. Predation by bears would substantially alter the distribution of nutrients from sea turtle nests that was quantified by Bouchard \& Bjorndal (2000) and shown to be important for maintaining dune vegetation in Florida (Hannan et al. 2007). Much attention has been given to the importance of the transfer of marine nutrients to terrestrial systems by brown bears Ursus arctos and black bears feeding on salmon in the Pacific Northwest (Schindler et al. 2003, Hilderbrand et al. 2004, Quinn et al. 2009). Clearly, a similar nutrient transfer by bears feeding on sea turtle eggs affected foodwebs in the coastal ecosystems of east Florida. In addition, predation by bears may have affected sea turtle population dynamics.

Management of raccoon populations in coastal protected areas such as Canaveral National Seashore in Florida provides an example of how knowledge of past predation by bears may affect current management decisions. In 1982, only 4 of 310 loggerhead clutches deposited in Canaveral National Seashore escaped predation by raccoons; in 1983, only $3 \%$ of unprotected sea turtle nests were not depredated by raccoons (McMurtray 1986). Resource managers in protected areas were faced with the difficult task of reconciling their mandate to protect threatened spe- cies (sea turtles) while employing ecosystem management to protect the natural roles of all species, including raccoons, in the beach ecosystem (Ratnaswamy \& Warren 1998). But what was natural for the raccoon populations? The proportion of nests that raccoons consumed under 'natural conditions' varies greatly depending on the baseline selected. Before bears were removed, raccoons were less important predators because of competition with bears and consumed many fewer eggs than in the 1980s (Romans 1775, also in the letter by Schubert). Schubert noted that during his boyhood ( 1894-1905), the bears missed only a few nests on Hutchinson Island, but during the week before he wrote his letter (June 1961), he walked along the same beach and 'noted that about a third of the nests had been robbed by raccoons.'

\section{CONCLUSION}

These accounts demonstrate the power of anecdotes. The series of reports with very similar descriptions from different sources over a long time period makes the role of bears as important predators of sea turtle eggs in Florida highly credible. This historical perspective provides a new vision and helps set a new baseline for evaluating ecological change in coastal Florida habitats and in sea turtle populations.

This summary, however, also reveals the limitations of anecdotes. Despite the value of these accounts, it is difficult to incorporate these qualitative accounts into the quantitative models that drive current environmental and population models and management efforts (Pauly 1995, Pitcher 2001, McClenachan et al. 2012, Soga \& Gaston 2018). The challenges of integrating anecdotes and local and traditional knowledge into modern environmental assessments must be met so that our conservation efforts have an improved historical perspective and appropriate recovery targets.

Acknowledgements. I thank A. Bolten for his continuing inspiration and support and for his constructive review of earlier drafts of the manuscript. M. Lamont, B. Mongiovi, B. Witherington, A. Gulick, R. Carthy, L. Soares, and A. Meade answered questions and provided valuable unpublished information. N. Constant created the map. I am grateful to G. Balazs for first sharing with me the letter from Wenzel J. Schubert to Archie Carr. I appreciate University of Florida librarians F. Turcotte, M. Wilbanks, and C. Van Ness for their assistance and dedication to preserving the archives of Archie Carr. Comments from B. Wallace and 2 anonymous reviewers improved the manuscript. 


\section{LITERATURE CITED}

Barbour T (1944) That vanishing Eden: a naturalist's Florida. Little, Brown \& Company, Boston, MA

Bjorndal KA, Bolten AB (2003) From ghosts to key species: restoring sea turtle populations to fulfill their ecological roles. Mar Turtle Newsl 100:16-21

Bouchard SS, Bjorndal KA (2000) Sea turtles as biological transporters of nutrients and energy from marine to terrestrial ecosystems. Ecology 81:2305-2313

Dodd CK Jr (1988) Synopsis of the biological data on the loggerhead sea turtle Caretta caretta (Linnaeus 1758). US Fish \& Wildl Serv Biol Rep 88

Dodge MM (ed) (1894) St. Nicholas Vol 21, Part 2. Scribner \& Co, New York, NY

ESRI Inc (2018) ArcMap (Version 10.6.0). ESRI Inc, Redlands, CA. https://desktop.arcgis.com/en/arcmap/

Fisher J, Hinde RA (1949) The opening of milk-bottles by birds. Br Birds 42:347-357

FWC (2019) Florida black bear management plan. Florida Fish and Wildlife Conservation Commission, Tallahassee, FL

FWC-FWRI (2017) Shoreline Polygon 1:12,000 Scale Florida 2004. Florida Fish and Wildlife Conservation Commission - Fish and Wildlife Research Institute, St. Petersburg, FL. http://geodata.myfwc.com/datasets/floridashoreline-1-to-12000-scale

*Hannan LB, Roth JD, Ehrhart LM, Weishampel JF (2007) Dune vegetation fertilization by nesting sea turtles. Ecology 88:1053-1058

Heithaus MR (2013) Predators, prey, and the ecological roles of sea turtles. In: Wyneken J, Lohmann KJ, Musick JA (eds) The biology of sea turtles, Vol III. CRC Press, Boca Raton, FL, p 249-284

Hilderbrand GV, Farley SD, Schwartz CC, Robbins CT (2004) Importance of salmon to wildlife: implications for integrated management. Ursus 15:1-9

Hirth HF (1997) Synopsis of the biological data on the green turtle Chelonia mydas (Linnaeus 1758). US Fish \& Wildl Serv Biol Rep 97

Jackson JBC (2001) What was natural in the coastal oceans? Proc Natl Acad Sci USA 98:5411-5418

Jackson JBC, Kirby MX, Berger WH, Bjorndal KA and others (2001) Historical overfishing and the recent collapse of coastal ecosystems. Science 293:629-637

Kawamura S (1959) The process of sub-culture propagation among Japanese macaques. Primates 2:43-60

Luckhardt AL, Luckhardt GE (2012) Historical vignette: when bears roamed Hutchinson Island. Treasure Coast Palm News. http://archive.tcpalm.com/yournews/martincounty/historical-vignettes-when-bears-roamed-hutchin son-island-ep-383116750-343477372.html

McClenachan L, Ferretti F, Baum JK (2012) From archives to conservation: why historical data are needed to set baselines for marine animals and ecosystems. Conserv Lett 5 : 349-359

McMurtray JD (1986) Reduction of raccoon predation on sea turtle nests at Canaveral National Seashore, Florida. Cooperative Park Studies Unit Tech Rep 20

Munroe K (1893) Canoemates; a story of the Florida Reef and Everglades. Harper \& Brothers, New York, NY

Murphy JM (1890) Turtling in Florida. Outing Mag 17: 97-103

Editorial responsibility: Bryan P. Wallace,

Fort Collins, Colorado, USA
Pandolfi JM, Bradbury RH, Sala E, Hughes TP and others (2003) Global trajectories of the long-term decline of coral reef ecosystems. Science 301:955-958

*Pauly D (1995) Anecdotes and the shifting baseline syndrome of fisheries. Trends Ecol Evol 10:430

Pauly D (2010) The ocean's shifting baseline. TED talk presented 15 April 2010. www.ted.com/talks/daniel_pauly _the_ocean_s_shifting_baseline?language=lo)

Pedersen GL, DeVries JM (2012) Pioneering Palm Beach: the Deweys and the South Florida frontier. The History Press, Charleston, SC

*Pitcher TJ (2001) Fisheries managed to rebuild ecosystems? Reconstructing the past to salvage the future. Ecol Appl 11:601-617

Quinn TP, Carlson SM, Gende SM, Rich HB Jr (2009) Transportation of Pacific salmon carcasses from streams to riparian forests by bears. Can J Zool 87:195-203

Ratnaswamy MJ, Warren RJ (1998) Removing raccoons to protect sea turtle nests: Are there implications for ecosystem management? Wildl Soc Bull 26:846-850

Romans B (1775) A concise natural history of East and West Florida. Printed for the author. New York. Available as facsimile reproduction: 1962, University of Florida Press, Gainesville, FL

* Schindler DE, Scheuerell MD, Moore JW, Gende SM, Francis TB, Palen WJ (2003) Pacific salmon and the ecology of coastal ecosystems. Front Ecol Environ 1:31-37

Scott C (2004) Endangered and threatened animals of Florida and their habitats. University of Texas Press, Austin, TX

Shamblin BM, Bolten AB, Bjorndal KA, Dutton PH and others (2012) Expanded mitochondrial control region sequences increase resolution of stock structure among North Atlantic loggerhead turtle rookeries. Mar Ecol Prog Ser 469:145-160

Soga M, Gaston KJ (2018) Shifting baseline syndrome: causes, consequences, and implications. Front Ecol Environ 16: 222-230

Stancyk SE (1982) Non-human predators of sea turtles and their control. In: Bjorndal KA (ed) Biology and conservation of sea turtles. Smithsonian Institution Press, Washington, DC, p 139-152

Standiford L (2002) Last train to paradise: Henry Flagler and the spectacular rise and fall of the railroad that crossed an ocean. Three Rivers Press, New York, NY

The Tropical Sun (newspaper) 10 June 1891, Vol 5, No. 16, p 1. https://ufdc.ufl.edu/UF00075915/00437/1x

USGS (2018) USGS National Boundary Dataset (NBD) for Florida 20180312 State or Territory Shapefile. US Geological Survey, National Geospatial Technical Operations Center, Rolla, MO. https://catalog.data.gov/dataset/ usgs-national-boundary-dataset-nbd-for-florida-201712 20-state-or-territory-shapefile2bd10

Webb CH (1887) Our bear on the beach. Harper's Young People 8:774-775

Williams G (2004) caribis - Caribbean Island Nations Coastline Boundaries: Open-File Report 2004-1400. US Geological Survey, Woods Hole, MA. https://pubs.usgs.gov/ of/2004/1400/data/boundaries/caribis/caribis.htm

Witzell WN (1983) Synopsis of biological data on the hawksbill turtle Eretmochelys imbricata (Linnaeus, 1766). FAO, Rome

Submitted: June 26, 2020; Accepted: August 25, 2020

Proofs received from author(s): November 5, 2020 